\title{
Holiness and impurity in the Torah and the Quran: Differences within a common typology
}

David M. Freidenreich

Colby College, dfreiden@colby.edu

Follow this and additional works at: https://digitalcommons.colby.edu/faculty_scholarship

Part of the Religion Commons

\section{Recommended Citation}

Freidenreich, David M., "Holiness and impurity in the Torah and the Quran: Differences within a common typology" (2010). Faculty Scholarship. 25.

https://digitalcommons.colby.edu/faculty_scholarship/25

This Article is brought to you for free and open access by Digital Commons @ Colby. It has been accepted for inclusion in Faculty Scholarship by an authorized administrator of Digital Commons @ Colby. 
[CIS 6.1-2 (2010) 5-22]

\title{
Holiness and Impurity in the Torah and the Quran: Differences within a Common Typology
}

\author{
David M. Freidenreich \\ Colby College \\ dfreiden@colby.edu
}

\begin{abstract}
In sharp contrast to the Torah's hierarchical conception of society, the Quran articulates an egalitarian worldview in which all humanity has equal access to the holiness that comes from being in relationship with God. Quranic egalitarianism serves to undermine biblically-grounded Jewish and Christian claims to elevated status. The significant differences in quranic and biblical discourse about both holiness and the antithetical state of impurity, however, can best be understood as existing within the framework of a common typology. Both the Torah and the Quran distinguish between impurity that results from physiological events and impurity caused by sin. These works, moreover, describe in similar ways the entirely different implications of these two types of impurity for a person's relationship with God. This essay demonstrates how the juxtaposition of the Torah and the Quran can enrich our understanding of these works and of broader religious phenomena.
\end{abstract}

\section{Keywords}

dietary laws, chosenness, holiness, impurity, Israelites, meat, Quran, Torah

"You shall be holy to Me," God declares to the People of Israel in the Torah, "for I the LORD am holy, and I have set you apart from other peo- 
ples to be Mine" (Lev. 20:26). ${ }^{1}$

The conception of Israel as set apart by God, permanently engaged in an exclusve relationship with the Deity and thus uniquely qualified to bear the title "holy," is central to the Torah and becomes a theological cornerstone of Judaism and Christianity alike. The Quran, of course, rejects the monopolistic claims to holiness voiced by Jews and Christians: "The Jews and the Christians say, 'We are God's children, his beloved ones.' Say: Why then does God punish you for your sins? No! You are human beings, a portion of what God created. God forgives whomever He pleases and punishes whomever He pleases" (Q 5:18). This verse, like the Quran more broadly, counters Jewish and Christian claims at two levels. Most obviously, the Quran emphasizes the sinfulness and unworthiness of those who received God's prior revelations (e.g., 5:12-15). In addition to this ad hominem attack, however, the Quran denies the very premise that underlies Jewish and Christian status claims. All humanity, the Quran asserts, is equally capable of attaining the holiness that comes from being in relationship with God.

Through a comparison of biblical and quranic rhetoric regarding meatrelated dietary laws, the first half of this essay demonstrates how the Quran "pokes holes in Israel's holiness" in the course of expressing ideas about status and authority that are more egalitarian than those embedded in the Torah. As the Quran is not based on the Torah or other biblical works, differences between the ideas expressed in these scriptures are unsurprising. Amidst these differences, however, the Quran and the Torah also share a number of key concepts in common. The second half of this essay demonstrates that impurity, a status antithetical to holiness and similarly intertwined with rhetoric about dietary law, is one such concept. Indeed, the types of impurity addressed in the Quran more closely resemble those found in biblical literature than those addressed within Islamic legal literature. The significant differences in quranic and biblical discourse about holiness and impurity, therefore, can best be

1. All translations of both the Torah and the Quran are my own. The former have been prepared in consultation with the JPS Hebrew-English Tanakh: The Traditional Hebrew Text and the New JPS Translation, 2nd ed. (Philadelphia: Jewish Publication Society, 1999), the latter in consultation with A. J. Arberry, trans., The Koran Interpreted (London: Allen \& Unwin, 1955); N. J. Dawood, trans., The Koran: With a Parallel Arabic Text (New York: Viking, 1990); Majid Fakhry, trans., An Interpretation of the Qur'an: English Translation of the Meanings, a Bilingual Edition (New York: New York University Press, 2002); Rudi Paret, trans., Der Koran (Stuttgart: Kohlhammer, 1966).

(C) Equinox Publishing Ltd. 2011

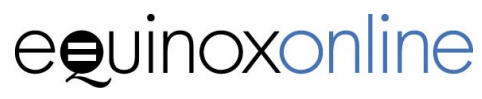


understood as existing within the framework of a shared typology.

This essay demonstrates ways in which the juxtaposition of the Torah and the Quran can enrich our understanding of these works and of broader religious phenomena as well. It shows the value of reading the Bible and the Quran not solely as independent documents or as the foundational scriptures of separate religious traditions but also as distinctive members of a Near Eastern literary corpus that spans the boundaries separating one religious community from another. The God of the Torah may have set Israel apart from other peoples and emphasized its uniqueness, but scholars of quranic and biblical literature need not follow suit.

\section{Poking holes in Israel's holiness: The different politics of the Quran and the Torah}

The biblical verse with which this essay begins appears in the context of rhetoric associated with the dietary laws.

I the LORD am your God who has set you apart from other peoples. So you shall set apart the pure animal from the impure, the impure bird from the pure. You shall not render your throats impure through animal or bird or anything with which the ground is alive, which I have set apart for you as impure. You shall be holy to Me, for I the LORD am holy, and I have set you apart from other peoples to be Mine. (Lev. 20:24b-26)

The Holiness strand of the Torah presents the distinctions between pure and impure species articulated in Leviticus 11 (and Deuteronomy 14:3-21) as analogous to the divinely ordained distinction between Israel and other peoples. In Jacob Milgrom's words, "as God has restricted his choice of the nations to Israel, so must Israel restrict its choice of edible animals to the few sanctioned by God." 2 The doctrine of chosennessthat God established a unique relationship with the People of Israel, a relationship that continues to the present day-is a key component of biblical and Jewish theology, and rhetoric about food practices is often linked to this doctrine.

Christian theology also embraces the biblical doctrine of chosenness. Israel does indeed stand in an eternal and unique relationship with God, the founders of the Church declared, and we Christians are the true People of Israel by virtue of our faith in Jesus Christ. The logic of this theology demands demonstration that Jews no longer constitute verus Israel:

2. Jacob Milgrom, Leviticus 1-16: A New Translation with Introduction and Commntary, Anchor Bible (New York: Doubleday, 1991), 724; see also the figure on p. 722.

(C) Equinox Publishing Ltd. 2011

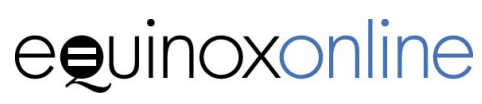


after all, only one religious community can be holy. Christian theologians in late antiquity thus felt the need to rebut the argument that contemporary Jews are the true People of Israel on account of their descent from biblical Israelites and continued adherence to biblical law. To do so, Christians ascribed new, negative meanings to the laws found in the Bible and emphasized the sinfulness of Israelites and Jews alike. The Letter of Barnabas, for example, asserts that biblical dietary laws are meant to be understood spiritually; the Jews mistakenly interpret these laws literally "because of their fleshly desires." In contrast to the statements of Leviticus indicating that dietary laws mark the holiness of Israel, the fourth-century Syriac writer Aphrahat asserts that these laws constitute punishments for Israelite sins. ${ }^{4}$ By toppling Israelites and their Jewish descendants from the pedestal of holiness, these theologians are able to claim that pedestal for Christians.

The Quran's response to biblical notions regarding holiness is more complex. Like the Bible, the Quran states that God did indeed choose and prefer the Children of Israel over all other peoples (e.g., Q 2:47, 44:32). Like the Christians, the Quran insists that the Children of Israel and their Jewish descendants lost this special status on account of their repeated transgressions (e.g., Q 7:161-67). As Uri Rubin observes, “The Qur'ān concentrates on the election of Israel only to show that the Children of Isarel have violated God's covenant and lost the status of God's chosen community." 5 The Quran, however, also undermines the very premise of Christian polemics against the Jews, namely the notion that only one group of people can stand in relationship with the divine. The Quran does not claim that its community of believers has assumed the mantle of Israel's holiness: God blesses the believers and establishes a covenant with them regardless of the fact that they are not Israel. It makes no difference who constitutes verus Israel today if, as the Quran asserts, Israel

3. Letter of Barnabas 10.9, translated in J. B. Lightfoot and J. R. Harmer, The Apostolic Fathers: Greek Texts and English Translations of Their Writings, 2nd ed. (Grand Rapids, MI: Baker Book House, 1992), 303.

4. Aphrahat, Demonstration 15.3-4, in Jacob Neusner, Aphrahat and Judaism: The Christian-Jewish Argument in Fourth-Century Iran (Leiden: Brill, 1971), 53-55. See also, among others, Novatian, Jewish Foods, trans. Russell J. DeSimone, in Novatian: The Trinity, The Spectacles, Jewish Food, In Praise of Purity, Letters, Fathers of the Church (Washington, DC: Catholic University of America Press, 1974), 137-161.

5. Uri Rubin, Between Bible and Qur'an: The Children of Israel and the Islamic Self-Image (Princeton, NJ: Darwin, 1999), 59.

(C) Equinox Publishing Ltd. 2011

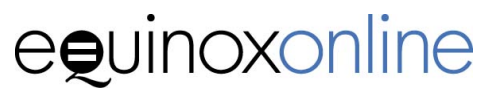


no longer bears intrinsic or unique holiness. quranic discourse about food reflects not only anti-Jewish polemic but also, and more importantly, the Quran's egalitarian conception of holiness.

Quranic norms regarding permitted and prohibited meat are, of course, far less detailed than those found in the Torah. "Say: In what has been revealed to me, I do not find anything prohibited for a person to eat except for carrion, blood spilled out, the flesh of swine-for these are impure $[\text { rijs }]^{6}$-or that [meat] over which, in a sinful act, a name other than God's was invoked" (Q 6:145; cf. 2:173, 5:3, 16:115). The Quran contrasts these norms with the laws that bind Jews: "As for the Jews, We prohibited every animal with claws and We prohibited the fat of cattle and sheep, except what their backs or entrails carry or what is mixed with bones. This is Our recompense to them for their transgression. We are surely Truthful" (6:146; cf. 4:160, 16:118). ${ }^{7}$ The Quran, like Aphrahat, presents the restrictions incumbent upon Jews as constituting a form of divine punishment justly meted out upon "the guilty people" (6:147). It thus transforms the distinctiveness made manifest by Jewish adherence to the dietary laws of the Torah from a sign of holiness into a mark of shame: Jews are the descendants of a people singled out not on account of their righteousness but rather on account of their stubbornness and sinfulness.

Quranic discourse about meat, however, does more than disparage the Jews. This discourse also communicates a worldview in which all human beings, not only those those who can claim to be Israel, are capable of observing the divine will and entering into relationship with God. Whereas the dietary laws of Leviticus are binding upon the People of Israel alone and serve to mark that community as uniquely holy, the Quran portrays the meat-related laws incumbent upon its audience of believers as universal. The Quran ridicules those who erroneously ascribe partners to God for their ignorance of these norms, and it

6. This explanatory phrase, fa-innahu rijs, is in the singular, leading various translators to understand it as applying solely to pork. In Q 5:90, however, rijs clearly applies to multiple items in a list (wine, gambling, idols, and divining arrows), all of which are the work of the devil and must be avoided. The singular antecedent for the pronoun in 6:145 is best identified as the implied "it" of "unless it is..." (illa an yakūn, which I translate idiomatically as "except for"). We will examine the meaning of the term rijs in the second half of this essay.

7. On the relationship between the Quran's account of Jewish dietary laws and their biblical counterparts, see Ze'ev Maghen, After Hardship Cometh Ease: The Jews as Backdrop for Muslim Moderation (Berlin: Walter de Gruyter, 2006), 146-160.

(C) Equinox Publishing Ltd. 2011

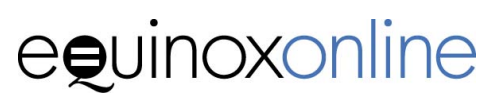


comdemns the bizarre food restrictions which these wrongdoers falsely ascribe to God ( $Q$ 6:135-144). These people should know better because God's truth is accessible to all. Similarly, the Quran consistently condemns non-believers for espousing false theology and demands that all human beings acknowledge Allah as being without peer. The Torah, in contrast, demands only that Israelites abstain from the worship of entities other than YHWH. By applying to all humanity laws that the Torah treats as distinctively Israelite, the Quran further undercuts claims that adherence to such norms marks contemporary Jews as uniquely holy.

The Quran's rejection of the notion that Israel bears a distinctly holy status clearly advances the political agenda of a community that cannot readily claim Israelite ancestry. More fundamentally, however, this rejection speaks to a difference between the Quran and the Torah regarding their respective conceptions of politics-that is, their ideas about how status and authority ought to be distributed within society. These conceptions of politics are especially apparent in discourse about the performance of animal slaughter. Leviticus, for example, grants to Israelite priests exclusive authority to perform the sacrificial rites necessary for slaughtering domestic animals. ${ }^{8}$ Although later authorities permit the non-sacral slaughter of such animals by all Israelites, the unique prerogative of priests to offer sacrifices remains intact in Jewish thought and, with respect to the Eucharistic sacrifice, within Christianity as well. Priests, by divine right, occupy an elevated status within Israel's hierarchical society.

The community of believers envisioned by the Quran, in sharp contrast, entirely lacks a priesthood. ${ }^{9}$ The Quran implies that all believersand, indeed, members of all nations-are eligible not only to perform non-sacral acts of animal slaughter but also to offer the sacrifice associated with the pilgrimage ( $\mathrm{Q} 22: 32-38)$. Islamic law and practice bear out the enfranchisement of all Muslims and, in another sharp departure from biblical norms, allow for performance of the sacrifice outside the precincts of the sacred shrine. The Torah envisions one people, one caste, one land, and one shrine as set apart from all others to partake of a unique relationship with the divine. Religious traditions founded upon biblical literature embrace in various ways this hierarchical, pyra-

8. Leviticus 17:3-9; see Baruch J. Schwartz, “Profane' Slaughter and the Integrity of the Priestly Code," Hebrew Union College Annual 67 (1996): 15-42.

9. It is telling that the entry "Priests" in the Encyclopaedia of the Quran $(=E Q)$ reads: "see Christians and Christianity; Monasticism and Monks; Asceticism."

(C) Equinox Publishing Ltd. 2011

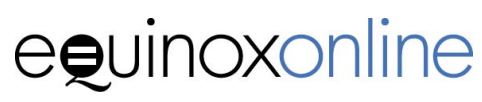


mid- or mountain-like conception of holiness. Quranic literature instead sketches a "flat-earth" vision of society, one that is far more egalitarian than the politics of the Torah.

The Quran's egalitarian conception of politics manifests itself even in contexts that do not advance the political efforts of nascent Islam to combat the claims of established Judaism or Christianity. One further food-related example demonstrates this point. Animal slaughter, even in non-sacrificial contexts, constitutes a religious ritual in the Near East in general and in the Quran in particular, as manifest in the requirement that the butcher invoke the name of God during the act of slaughter (Q 6:118-121). Although Jewish authorities permit non-priests to perform such an act, they do not allow adherents of alien traditions to do so: foreigners, after all, bear inferior status. Christian authorities not only forbid the consumption of meat from idolatrous sacrifices (Acts 15:29), they come to prohibit meat prepared by Jewish butchers as well. The Quran, in contrast, explicitly allows Muslims to eat meat from animals slaughtered by Jews or Christians, and vice versa. ${ }^{10}$

Within the context of a passage that addresses laws governing permitted and prohibited meat, God declares:

Today the good things are permitted to you, and the food of those who were given the Book is permitted to you, and your food is permitted to them. So are the chaste women among the believers and the chaste women among those who were given the Book before you, provided you give them their dowries and take them in chastity, not in wantonness or as mistresses. (Q 5:5)

The Quran's egalitarian ethos encompasses all those who received an authentic scripture, at least with respect to the act of animal slaughter. Indeed, the very recognition of the Torah and Gospels as authentic divine revelations presumes that God has established relationships with multiple religious communities and that no single community can claim a monopoly on holiness. The Quran, of course, elevates the status of its own community over that of Jews and Christians in other respects, including through the prohibition, implicit in this verse, against the marriage of a Muslim woman to a Jewish or Christian man. ${ }^{11}$ These claims,

10. On religious norms governing meat prepared by adherents of other religions, see David M. Freidenreich, Foreigners and Their Food: Constructing Otherness in Jewish, Christian, and Islamic Law (Berkeley: University of California Press, 2011).

11. As Yohanan Friedmann, Tolerance and Coercion in Islam: Interfaith Relations in the Mus-

(C) Equinox Publishing Ltd. 2011

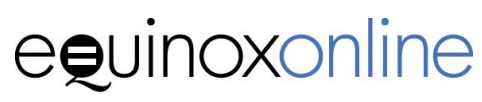


however, are not based on the assertion that God has set apart one community as uniquely holy. Indeed, the Quran holds out the possibility that Jews, Christians, and Sabians can stand in right relationship with God and earn God's ultimate reward alongside Muslims (e.g., Q 2:62). The Torah and its adherents, in contrast, reserve the lion's share of God's blessings for those who qualify as "Israel."

The Quran's conception of politics and, thus, of holiness itself differs fundamentally from that of the Torah. Although the Quran draws on aspects of biblical law and narrative for polemical and other purposes, the ideas it expresses are often quite different from those found in biblical literature. Juxtaposition of the Quran and the Torah affords us an opportunity to better appreciate the distinctive political theories that underlie each of these texts, as we might not otherwise notice what makes each political system distinctive. ${ }^{12}$ Juxtaposition of the Quran and the Torah, however, also reveals significant similarities in the way these works conceive of certain phenomena, including the phenomenon of impurity, a state antithetical to holiness. ${ }^{13}$

\section{Impurity and sin in the Torah and the Quran: A common typology}

Western Islamicists, to the extent that they devoted any attention to quranic and Islamic discourse about impurity, once commonly regarded such discourse to be little more than a pale reflection of biblical and Jewish norms. ${ }^{14}$ In recent years, scholars have correctly rejected this under-

lim Tradition (Cambridge: Cambridge University Press, 2003), 161, observes, "A marriage of a Muslim woman to a non-Muslim man would result in an unacceptable incongruity between the superiority which the woman should enjoy by virtue of being Muslim, and her unavoidable wifely subservience to her infidel husband."

12. On the use of comparison to draw scholarly attention to "the dog that doesn't bark" (à la Sherlock Holmes), see Wendy Doniger, The Implied Spider: Politics and Theology in Myth (New York: Columbia University Press, 1998), 33-41.

13. The terms "holy" and "impure" are not antonyms: the opposite of "holy" is "common," not "impure," and not everything common is impure. These terms are, however, antithetical because nothing impure can ever be holy and exposure of the holy to the impure can have calamitous consequences. On the relationship between the dichotomous pairs holy/common and pure/impure, see Milgrom, Leviticus 1-16, 731-732.

14. Ze'ev Maghen, "Much Ado About Wudü'," Islam 76 (1999): 230, states that only two scholars, Wensinck and Bousquet, devoted so much as an article to the subject of impurity in Islam before the 1980s. In "First Blood: Purity, Edibility, and the Independence of Islamic Jurisprudence," Islam 81 (2004): 53-57, Maghen cites a wider range of Islamicists-Wensinck, Goldziher, Schacht, Rosenthal, Crone-who claim

(C) Equinox Publishing Ltd. 2011

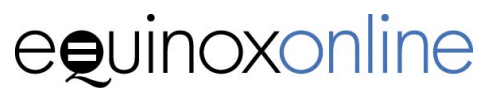


standing in the course of highlighting both the independence of the Islamic system of impurity and significant differences between this system and its Jewish counterpart..$^{15}$ Efforts to interpret Islamic discourse about impurity on its own terms have unquestionably furthered scholarly understanding of this material, but I would suggest that the pendulum has swung too far away from comparativism. Juxtaposition of the Quran and the Torah reveals that these works speak of common types of impurity, including a type absent from later Islamic sources. Interpretation of the Quran exclusively in light of these post-quranic works yields a strained understanding of the Quran's own discourse about impurity.

Classical Islamic sources speak of two distinct types of impurity. The first type, hadath, constitutes a state of pollution endured by human beings after the occurrence of various physiological events (e.g., urination, menstruation, sexual intercourse). The second type, najāsa, constitutes a state of intrinsic impurity ascribed to specific objects (e.g., urine, blood, semen) and animals (e.g., pigs, dogs). ${ }^{16}$ Most authorities hold that human beings cannot themselves become najis, intrinsically impure. Humans do, however, regularly find themselves in a "major" or "minor" state of hadath impurity because one need not-indeed, one simply cannot-avoid experiencing polluting events. There is nothing wrong with enduring circumstantial pollution of this nature provided

that the Islamic system of impurity constitutes little more than a carbon copy of its Jewish predecessor.

15. See Maghen, "First Blood," which highlights the differences between the place of blood in these two systems of impurity in the course of making a broader case against treating Islamic impurity discourse as a mere derivative of Jewish discourse on this subject. Also relevant is Maghen's "Close Encounters: Some Preliminary Observations of the Transmission of Impurity in Early Sunni Jurisprudence," Islamic Law and Society 6 (1999): 348-392, which demonstrates that, in sharp contrast to their Jewish counterparts, Sunni authorities insist that the human body cannot become impure. More broadly, Sunnis hold that impurity is never contagious; the issue of communicability constitutes a significant element of biblical and rabbinic systems of impurity. Critique of earlier approaches to the study of Islamic impurity discourse is also implicit in Marion Holmes Katz, Body of Text: The Emergence of the Sunni Law of Ritual Purity (Albany: State University of New York Press, 2002), 1-27.

16. The term najāsa is also used to refer to impurity in general. The clearest summary of the Islamic impurity system of which I am aware appears in Richard Gauvain, "Ritual Rewards: A Consideration of Three Recent Approaches to Sunni Purity Law," Islamic Law and Society 12 (2005): 341-343; see also Katz, Body of Text, 2; Maghen, "First Blood," 51-52; A. Kevin Reinhart, "Impurity/No Danger," History of Religions 30 (1990): 1-24.

(C) Equinox Publishing Ltd. 2011

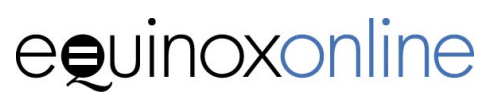


that one performs the requisite purificatory rituals before subsequently engaging in prayer or certain other religious activities that make manifest one's relationship with God. There is nothing wrong with objects defined as najis either; such objects simply may not be present on the body or clothing of a person who wishes to engage in prayer or similar activities. ${ }^{17}$ The concept of sin thus has no place within the system of impurity elaborated in Islamic legal sources.

The Quran discusses non-sinful impurity of the hadath type on several occasions, using the term junub to refer to the bearer of impurity and employing forms of the verb t.h.r. to refer to the act of purification required before such a person engages in prayer $(Q 2: 222,4: 43,5: 6){ }^{18}$ Other terms associated with the verb ț.h.r., however, consistently operate within the conceptual framework of sinfulness. Chief among these terms is rijs, a word we encountered in the statement of quranic dietary laws cited above: carrion, blood, and pork, foodstuffs whose consumption is sinful, are defined as rijs (6:145). Elsewhere, the Quran defines wine, divining arrows, and the accoutrements of gambling as "rijs of the Devil's doing" and enjoins believers to "shun" these objects associated with sinful activities (5:90). ${ }^{19}$ Believers are also to "shun the rijs associated with idols and shun words of falsehood" (22:30), two intangible objects similarly linked with offensive behavior. The command "shun," ijtanaba, links discourse about rijs to discourse about the junub. The nature of rijs as a type of impurity is also evident in Quran 33:33, which reports that God, speaking to the Prophet's wives, wishes "to remove rijs from you, O People of the House, and to thoroughly purify you (wa-yutahhirakūm tathi $\left.i^{a n}\right)$." Rijs, however, does not refer to impurity that results from the occurrence of a physiological event but rather to a type of impurity that specifically afflicts objects and people associated with offensive, sinful activity. Unlike people in a state of hadath impurity, who have done nothing wrong, beings defined as rijs are intensely abhorrent. ${ }^{20}$

17. Contact with a najis substance does not render a person impure according to Islamic authorities: once that substance is removed, no further purificatory ritual is necessary to render the person fit for the performance of the prayer.

18. On these verses, see Katz, Body of Text, 29-58, and, in brief, Katz's entry, "Cleanliness and Ablution," EQ 1:341-344.

19. Gambling and the consumption of wine are defined as sinful in 2:219, while the use of divining arrows as a means of distributing meat is so characterized in 5:3.

20. See further Toshihiko Izutsu, Ethico-Religious Concepts in the Qur'ān, reprint, 1966 (Montreal and Kingston: McGill-Queen's University Press, 2002), 240-241.

(C) Equinox Publishing Ltd. 2011

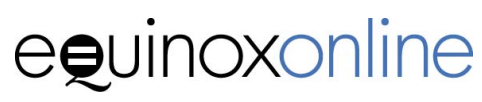


Numerous verses ascribe rijs to sinful individuals and groups, particularly those characterized by disbelief in God and in God's teachings, and it is evident that God regards such people as enemies. The Quran describes those who spurn God's revelations to the Prophet as being in a state of rijs (9:125), warns that those who are rijs are destined for Hell (9:95), and declares that God inflicts rijs upon unbelievers as a form of punishment $(6: 125,7: 71,10: 100)$. That this punishment takes the form of impurity is suggested by Quran 33:33, in which the removal of rijs is associated with purification, and by the fact that this term applies to objects that cannot endure other forms of punishment in any meaningful sense.

Other quranic terms also seem to refer specifically to a type of impurity associated with people who engage in offensive behavior. Numerous verses employ the term rijz in reference to a divine punishment that afflicts sinful individuals or communities (Q 2:59, 7:134-35, 7:162, 29:34, $34: 5,45: 11)$. Quran 8:11 indicates that this term refers to a form of impurity, as it reports that God "purified" members of the Quran's audience and relieved them of "the Devil's rijz." The apparently related term rujz also appears in conjunction with rhetoric about purification (74:4-5). Another member of this constellation of terms is najas, which in the Quran refers not to the state of intrinsically impure objects but rather to people who ascribe partners to God, perhaps the greatest offense within the Quran (9:28). ${ }^{21}$

Islamic interpreters typically understand rijs and related quranic

21. On the interrelations among the terms rijs, rijz, rujz, and najas, see also Joseph E. Lowry, "Ritual Purity," EQ, 5: 502-504. Most Sunni authorities-and, following in their footsteps, most modern translators of the Quran-interpret the najas which the Quran ascribes to human beings metaphorically. Alternatively, these authorities suggest that this term refers to the semi-permanent state of hadath impurity which affects non-Muslims for the simple reason that they fail to perform the requisite ablutions on a regular basis. Most Shi i authorities, in contrast, define non-Muslims as intrinsically impure in much the same manner as substances like wine, pigs, and urine. This intrinsic impurity, Shi is explain, results from the false theology espoused by non-Muslims and disappears at the moment of a non-Muslim's conversion to Islam. Shi'i authorities thus conflate the impurity that stems from offensive beliefs and behaviors with the impurity intrinsic in certain substances. See Ze'ev Maghen, "Strangers and Brothers: The Ritual Status of Unbelievers in Islamic Jurisprudence," Medieval Encounters 12 (2006): 173-223; David M. Freidenreich, "The Implications of Unbelief: Tracing the Emergence of Distinctively Shi i Notions Regarding the Food and Impurity of Non-Muslims," Islamic Law and Society 18 (2011): 53-84. See also Janina M. Safran, "Rules of Purity and Confessional Boundaries: Maliki Debates About the Pollution of the Christian," History of Religions 42 (2003): 197-212.

(C) Equinox Publishing Ltd. 2011

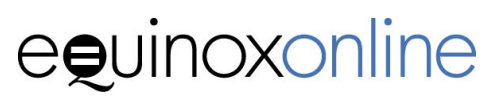


terms within the classical legal framework of najāsa, perhaps because substances like wine, carrion, and pigs can readily be ascribed intrinsic impurity. ${ }^{22}$ This framework, however, accounts neither for the ascription of rijs-type impurity to human beings nor for the consistent association of such impurity with sinfulness; after all, there is nothing sinful about najis substances like urine or semen. Contemporary scholars, seeking to understand the Quran solely in relationship with the Islamic tradition, nevertheless often follow in the footsteps of classical authorities in associating terms like rijs with intrinsic impurity even as they acknowledge the imperfect fit. ${ }^{23}$ We can better understand the meaning of rijs and related terms in their quranic context, I contend, by reading the Quran not only in light of the Islamic interpretive tradition but also in juxtaposition with the Torah and contemporary biblical scholarship.

Whereas the Islamic system of impurity speaks of a single type of impurity that affects human beings, the hadath type, biblical scholars have observed that the Torah and ancient Jewish literature alike speak of two distinct types of impurity that affect human beings, types which we may label as circumstantial impurity and offensive impurity. Both forms of impurity are incompatible with holiness, but their causes and consequences are entirely different. Failure to properly distinguish one type from another, scholars have demonstrated, results in profound misunderstandings of texts about impurity.

Jonathan Klawans, author of the principal study on the distinction between circumstancial and offensive impurity, characterizes the former as "natural, more or less unavoidable, generally not sinful, and typically impermanent." ${ }^{24}$ Impurity of this nature results from the occurrence of

22. This association was evidently commonplace: E. W. Lane, Arabic-English Lexicon (Cambridge: Cambridge University Press, 1863), s.v. r.j.s., cites several medieval lexicographers who discuss popular phrases such as rijs nijs.

23. See, for example, Lowry, "Ritual Purity," who discusses rijs and related terms under the heading "substantive [i.e., intrinsic] impurity" even as he acknowledges that "the qur'ānic notion of substantive impurity appears particularly abstract and ideological rather than matter-driven" (p. 502). See also Katz, Body of Text, 54-55, who understands references to the rijs of nonbelievers to refer both to their unbelief and to their intrinsic impurity. A. Kevin Reinhart, "Contamination," EQ 1: 410-412, in contrast, implies that neither of the quranic terms rijs and najas are truly references to impurity in the classical Islamic sense of that term. In "Impurity/No Danger," focused on the classical Sunni system of impurity, Reinhart sees no need to address the term rijs.

24. Jonathan Klawans, Impurity and Sin in Ancient Judaism (Oxford: Oxford University

(C) Equinox Publishing Ltd. 2011

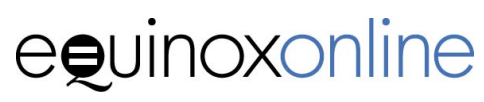


certain physiological events and from contact with certain intrinsically impure substances. The pollution associated with this state of impurity must be alleviated before the person who suffers from it is fit to approach the precincts of the Israelite sanctuary.

Klawans' definition of circumstantial impurity aptly accounts for discourse about hadath-type impurity found in the Quran and Islamic legal literature, notwithstanding the significant differences between biblical and Islamic sources with respect to details regarding the events that result in circumstantial impurity and how such pollution may be alleviated. One difference I would highlight in the present context (others may be found in n. 15) is that the Torah emphasizes the need for individuals affected by circumstantial impurity to purify themselves before entering the Israelite sanctuary, a specific space characterized by its unique holiness. The Quran, in contrast, focuses on purification prior to prayer, a geographically non-specific activity, and offers special accommodations for those whose travels prevent the usual form of purificatory ablutions (Q 4:43, 5:6). We see here another instance of the difference between biblical and quranic conceptions of holiness, but this difference manifests itself within the common conceptual framework of circumstantial impurity.

Klawans observes that the second type of impurity that affects humans

Press, 2000), 41. Klawans uses the terms ritual and moral impurity rather than circumstantial and offensive impurity; the latter terms are my own. I prefer circumstantial over ritual for two reasons. Ritual is an ambiguous adjective often applied to the entirety of a religious system of impurity; see, for example, the entry "Ritual Impurity" in the Encyclopaedia of the Quran. When applied in the narrower sense intended by Klawans, ritual refers to the kinds of behavior a person in this state of impurity may not perform or (in many but not all cases) the nature of the purificatory activity that alleviates this state. Circumstantial, in contrast, is an adjective that lacks a pre-established connotation with respect to impurity. It refers, moreover, to the circumstances that cause this state of impurity, information that is of more direct relevance than the implications of such a state. I use offensive rather than moral to characterize the second type of impurity both because the former adjective refers more directly to the sinful action that causes this state of impurity and because not all offenses that result in such impurity, in either the biblical or the quranic context, fall into the realm of morality as we commonly understand that term today. I consider circumstantial and offensive to be superior to the adjectives tolerated and prohibited employed by David P. Wright, "The Spectrum of Priestly Impurity," in Priesthood and Cult in Ancient Israel, ed. Gary A. Anderson and Saul M. Olyan (Sheffield, England: JSOT Press, 1991), 150-181, both because these terms relate to the cause of the impurity and because they lend themselves more naturally to construction as adverbs.

(C) Equinox Publishing Ltd. 2011

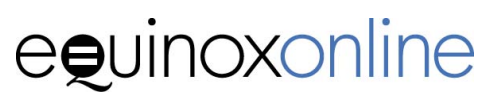


in the Torah, offensive impurity, "results from committing certain acts so heinous that they... bring about an impurity that morally-but not ritually-defiles the sinner, the land of Israel, and the sanctuary of God." ${ }^{25}$ Internal quranic evidence indicates that the term rijs refers specifically to offensive impurity of the type Klawans describes. There are, once again, significant differences of detail between biblical and quranic statements regarding this type of impurity, but these differences exist within a common conceptual framework. The Quran, unlike the Torah, ascribes offensive impurity to people who are not members of its community of addressees. Only biblical literature suggests that offensive impurity defiles a specific land or sanctuary. These differences correlate to the conceptions of holiness we observed in the first half of this essay. Only people and spaces which can bear the status "holy"- that is, those eligible to stand in close relationship with God-are affected by the defilement that results from offensive impurity and precludes connection with the divine. Both works treat offensive impurity as utterly antithetical to holiness and employ rhetoric about such impurity as a means of warning believers about the consequences of breaching their covenantal obligations to God. Indeed, both the Torah and the Quran emphasize that violation of the norms of monotheistic worship constitutes a defiling offense. The Quran lacks the Torah's emphasis on the defiling nature of illicit sexual behavior, most likely because the Quran defines its community of believers solely in terms of absolute monotheism whereas the Torah distinguishes Israelites from foreigners by reference to its sexual as well as cultic norms. ${ }^{26}$

The quranic concept of rijs is not synonymous with the later category of najāsa but rather functions within a distinct conceptual framework. Juxtaposition of the Torah and the Quran enables us to recognize that

25. Klawans, Impurity and Sin, 26, emphasis original and citation of biblical prooftexts omitted. On the terms Klawans emphasizes, see the prior note. On the implications of offensive defilement for the Israelite sanctuary, see Jacob Milgrom, "Israel's Sanctuary: The Priestly ‘Picture of Dorian Gray', Revue Biblique 83 (1976): 390-399.

26. Thus Leviticus 20:23-24a, immediately preceding the verses about Israelite holiness cited near the beginning of this essay, instructs Israelites not to emulate the cultic and, especially, sexual practices ascribed to the Canaanites. The presentation of similar sexual norms in Quran 4:22-23, in contrast, does not function rhetorically as a means of distinguishing the Quran's audience from foreigners. It is possible that Quran 33:32-33 alludes to the notion that adultery constitutes a defiling offense, but if so this would be the only instance in which rijs relates specifically to norms of proper sexual activity.

(C) Equinox Publishing Ltd. 2011

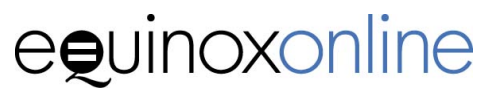


the Quran too speaks of offensive impurity, resulting from the transgression of major taboos, in addition to the circumstantial impurity that results from the occurrence of certain physiological events. The classical Islamic conception of najāsa constitutes a third type of impurity, which we may define as intrinsic impurity. ${ }^{27}$ This type of impurity, absent from the Quran, is also attested in the Torah's depiction of impure animal species and such objects as human corpses. Scholars of biblical literature, who focus primarily on types of impurity that apply to living human beings, have not devoted much attention to this third type of impurity. I have found the three-category typology of circumstantial, offensive, and intrinsic impurity developed through the study of Jewish and Islamic sources to provide a valuable framework for the analysis not only of these sources but Christian discourse about impurity as well. ${ }^{28}$ Juxtaposition of the Torah and the Quran thus not only fosters scholarly appreciation of significant similarities and differences between these works but also furthers our efforts to understand broader religious phenomena, including concepts of impurity and holiness.

\section{登誉}

Scholars of the Quran and other Islamic texts can benefit from analyzing parallel material in biblical literature because awareness of similarities and differences between these works furthers our ability to understand the Islamic literature, as well as broader religious phenomena. Unlike Islamicists of earlier generations, many of whom treated Islamic sources as derivative of their biblical and Jewish predecessors, we may profitably conceive of the relationship between the Quran and biblical literature as analogous to the relationship between the Bible and Ancient Near Eastern literature. Significant chronological and geographic gaps separate Ancient Near Eastern texts from the Torah, and no one would posit that the Genesis flood narrative is merely derivative of the Gilgamesh epic or that Exodus' Covenant Code is a pale reflection of the Code of Hammurabi. Despite the differences between these works, however, analysis of sources from the Ancient Near East yields valuable insights regarding concepts, laws, and terms found in the Hebrew Bible. Indeed, scholars

27. Katz, Body of Text, 2, translates najāsa as "substantive impurity." This definition is apt, but the adjective intrinsic has the advantage of lending itself more naturally to construction as an adverb.

28. See Freidenreich, Foreigners and Their Food.

(C) Equinox Publishing Ltd. 2011

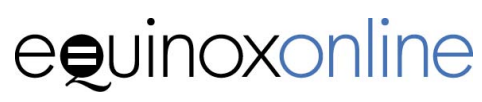


have long recognized that pre-biblical sources sometimes offer more relevant testimony to the original meaning of a text than post-biblical interpretive traditions. Scholars of the Quran, recognizing the often significant differences between the original meaning of the text and the interpretations offered by later Islamic authorities, can likewise profitably turn to biblical literature as an alternative source of insights even while affirming the independence and originality of the Quran itself.

Biblical scholarship has long since poked holes in Israel's set-apartness, if not its claims to holiness, through the juxtaposition of biblical and Ancient Near Eastern literature. Such comparisons have illuminated both commonly held conceptions and those that are distinctively Israelite. Similar results emerge from the juxtaposition of biblical literature and the Quran. We can improve our understanding of both sets of texts through the examination of their commonalities and their differences, as well as through sharing the fruits of scholarship into quranic and biblical literature across disciplinary boundaries. We might even say the Quran itself, through its ascription of potential holiness to all peoples and its explicit permission of sharing food among Jews, Christians, and Muslims, encourages such eclecticism. ${ }^{29}$

\section{Bibliography}

Arberry, A. J., trans. The Koran Interpreted. London: Allen \& Udwin, 1955.

Dawood, N. J., trans. The Koran: With a Parallel Arabic Text. New York: Viking, 1990.

Doniger, Wendy. The Implied Spider: Politics and Theology in Myth. New York: Columbia University Press, 1998.

Fakhry, Majid, trans. An Interpretation of the Qur'an: English Translation of the Meanings, a Bilingual Edition. New York: New York University Press, 2002.

Freidenreich, David M. Foreigners and Their Food: Constructing Otherness in Jewish, Christian, and Islamic Law. Berkeley: University of California Press, 2011. "The Implications of Unbelief: Tracing the Emergence of Distinctively Shi'i Notions Regarding the Food and Impurity of NonMuslims." Islamic Law and Society 18(2011): 53-84. http://dx.doi. org/10.1163/156851910X517074

Friedmann, Yohanan. Tolerance and Coercion in Islam: Interfaith Relations in the Muslim Tradition. Cambridge: Cambridge University Press, 2003. http://

29. A version of this paper was presented in the framework of the Society of Biblical Literature's "Quran and Biblical Literature" program unit in 2008. I am grateful to Kathryn M. Kueny for chairing this program unit and to Michael Pregill for organizing the panel on the "Muslim Bible" in which this paper was delivered.

(C) Equinox Publishing Ltd. 2011

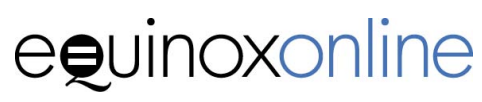


dx.doi.org/10.1017/CB09780511497568

Gauvain, Richard. "Ritual Rewards: A Consideration of Three Recent Approaches to Sunni Purity Law." Islamic Law and Society 12 (2005): 333-393. http:// dx.doi.org/10.1163/1568519057746008251

Izutsu, Toshihiko. Ethico-Religious Concepts in the Qur'ān. 1966. Montreal \& Kingston: McGill-Queen's University Press, 2002.

JPS Hebrew-English Tanakh: The Traditional Hebrew Text and the New JPS Translation. 2nd ed. Philadelphia, PA: Jewish Publication Society, 1999.

Katz, Marion Holmes. Body of Text: The Emergence of the Sunni Law of Ritual Purity. Albany: State University of New York Press, 2002.

"Cleanliness and Ablution." In Encyclopaedia of the Qur'an, 1: 341-344. Leiden: Brill, 2001.

Klawans, Jonathan. Impurity and Sin in Ancient Judaism. Oxford: Oxford University Press, 2000. http://dx.doi.org/10.1093/acprof:oso/9780195132908.001. 0001

Lane, E. W. Arabic-English Lexicon. Cambridge: Cambridge University Press, 1863.

Lightfoot, J. B., and J. R. Harmer, eds. The Apostolic Fathers: Greek Texts and English Translations of Their Writings. 2nd ed. Grand Rapids, MI: Baker Book House, 1992.

Lowry, Joseph E. "Ritual Purity." In Encyclopaedia of the Qur'an, 5: 498-508. Leiden: Brill, 2001.

Maghen, Ze'ev. After Hardship Cometh Ease: The Jews as Backdrop for Muslim Moderation. Berlin: Walter de Gruyter, 2006.

. "Strangers and Brothers: The Ritual Status of Unbelievers in Islamic Jurisprudence." Medieval Encounters 12 (2006): 173-223. http://dx.doi. org/10.1163/157006706778884925

"First Blood: Purity, Edibility, and the Independence of Islamic Jurisprudence." Islam 81 (2004): 49-95. http://dx.doi.org/10.1515/ islm.2004.81.1.49

. "Close Encounters: Some Preliminary Observations of the Transmission of Impurity in Early Sunni Jurisprudence." Islamic Law and Society 6 (1999): 348-392. http://dx.doi.org/10.1163/1568519991223784 "Much Ado About Wudū'." Islam 76 (1999): 205-252.

Milgrom, Jacob. "Israel's Sanctuary: The Priestly 'Picture of Dorian Gray'." Revue Biblique 83 (1976): 390-399.

Leviticus 1-16: A New Translation with Introduction and Commntary. Anchor Bible. New York: Doubleday, 1991.

Neusner, Jacob. Aphrahat and Judaism: The Christian-Jewish Argument in FourthCentury Iran. Leiden: Brill, 1971.

Novatian. "Jewish Foods." Translated by Russell J. DeSimone. In Novatian: The Trinity, The Spectacles, Jewish Food, In Praise of Purity, Letters. Fathers of

(C) Equinox Publishing Ltd. 2011

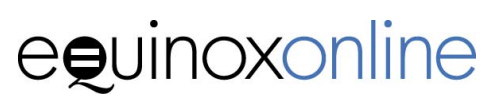


the Church, Vol. 67, 137-161. Washington, DC: Catholic University of America Press, 1974.

Paret, Rudi, trans. Der Koran. Stuttgart: Kohlhammer, 1966.

Reinhart, A. Kevin. "Contamination." In Encyclopaedia of the Qur'an, 1: 410-412. Leiden: Brill, 2001.

.Impurity/No Danger." History of Religions 30 (1990): 1-24. http://dx.doi. org/10.1086/463212 // http://www.jstor.org/stable/1062790

Rubin, Uri. Between Bible and Qur'an: The Children of Israel and the Islamic Self-Image. Princeton, NJ: Darwin, 1999.

Safran, Janina M. "Rules of Purity and Confessional Boundaries: Maliki Debates About the Pollution of the Christian." History of Religions 42 (2003): $197-$ 212. http://dx.doi.org/10.1086/375036

Schwartz, Baruch J. "'Profane' Slaughter and the Integrity of the Priestly Code." Hebrew Union College Annual 67 (1996): 15-42.

Wright, David P. "The Spectrum of Priestly Impurity." In Priesthood and Cult in Ancient Israel, edited by Gary A. Anderson and Saul M. Olyan, 150-181. Sheffield, England: JSOT Press, 1991.

(c) Equinox Publishing Ltd. 2011 